\title{
Fernando Pessoa's Diasporic Ulysses of Transmutation and Settled Argonaut of Sensations Alberto Caeiro
}

\author{
Lisandra Sousa \\ ziglisazag@hotmail.com
}

Ulysses, the Greek tragic hero, has been part of the Portuguese imaginary since Portugal's formation as a nation. As stated in the Encyclopaedia Brittanica, "the city's name is a modification of the ancient Olisipo (Ulyssipo), and its founding has been attributed to various sources including Ulysses (Odysseus), the hero of Homer's Odyssey"; Elisha, who was purported to have been a grandson of the Hebrew patriarch Abraham; and, more credibly, Phoenician colonists. As a "mute" creator of then ation, Fernando Pessoa's Ulysses in Mensagem reveals the ambiguity of countless dispossessed, nameless, and displaced nationals, whereas the national narrative, Os Lusíadas, never acknowledged the contributions of the displaced nationals to the nation. Consequently, the modernist poet Pessoa, advances with a Ulysses of modernity in order to intervene in the historicism of the nation, that is, a view which, according to Homi Bhabha, leads to "(...) a succession of historical moments that represent an eternity produced by self-generation" (1994, p. 299). As Homi suggests, in the performative discourses of the nation, "potent symbolic and affective sources of cultural identity served to displace the historicism that had dominated discussions of the nation as a cultural force" (1994, p. 201). In order to disrupt notions of the nation as a cultural force, Pessoa reconceptualises nationhood in modernity. For this purpose, the poet 
compiles a series of poems that he writes throughout the years, and that would be called "Portugal" at first, until Pessoa decides that such a title is unable to contain in its physical and mental boundaries the work that has become known as Mensagem. Therefore, by advancing a double-bind for the nation, he writes, with Mensagem, a modern relocation of mythical figures in Camões's Os Lusíadas, and, at the same time, he creates his heteronyms. In this way, the poet suggests a mapping for the nation that is transnational and translational. Himself a diasporic identity who was educated in South Africa, during the reign of Queen Victoria, Pessoa returns to Portugal and understands that Portuguese literature is in need of a temporality that ought to recognize the cultural ambivalence of the nation. As a result, he displaces heteronym Ricardo Reis to Brazil in exile for being monarquic; he exiles semi-heteronym Bernardo Soares as a bookkeeper in Lisbon; and he creates Álvaro de Campos who travels widely and studies at the University of Glasgow, returning later to unemployment in Portugal; finally, Pessoa also reveals the master Alberto Caeiro who is a migrant in Portugal as another displaced identity whose poetry liberates those who come to read it, including the heteronyms and Pessoa himself. The heteronyms and Pessoa himself are, therefore, an entire nation dispersed throughout the world, yet in dialogue in the space that their modern poetry creates.

In the next sections, an analysis of Fernando Pessoa's poem "Ulisses," "the nothing that is everything" and the "brilliant and mute" myth, will be followed by an interpretation of Pessoa's Ulysses of modernity. I will also argue that the poet's heteronyms are the paramount example of his non-positioning of Portugal's national and literary identity. In order to accomplish this goal, I explore how a cultural identity of dispersal in the world - diasporic identities -, and in the territory - settled identities -, imply a repositioning relative to the national culture(s), and positioning relative to the culture(s) encountered. In this essay, Pessoa's Ulysses of modernity is regarded as a diasporic identity, while the heteronym Alberto Caeiro represents the poet's settled identity.

\section{THE BRILLIANT AND MUTE ULYSSES IN PORTUGUESE DISPOSSED, NAMELESS, DISPLACED}

According to legends based on etymological studies on the works of Strabos, Solinus, and other scholars, Ulysses discovers Lisbon, the city 
hosting his ancient name of Olisipona or Ulixibona, whilst on his odyssey through the Mediterranean (BOITANI, 1994, pp. 18-19). Ulysses reappears in the Portuguese epic of Camões' Os Lusíadas, in the sixteenth century, a work highly influenced by the European culture of the Renaissance. Ulysses resurfaces in the context of the maritime expansion of Portugal, as he is part of a pantheon of historical figures and heroes of the Portuguese "collective imagination" (MATTOSO, 2008, p. 35). He is, therefore, an icon of human subjects who depart from "[Portugal's] occidental praia Lusitana," by "mares nunca de antes navegados" [oceans where none had ventured before] for the foundation of a "Novo Reino" [New Kingdom] (CAMÕES, n.d., p. 43). In Canto II, the speaker nostalgically recalls Portugal's "memórias gloriosas" [glorious memories] and by gone "obras valerosas" [immortal deeds] in order to introduce the Portuguese Ulysses in Canto I:3:

\author{
Cessem do sábio Grego e do Troiano \\ As navegações grandes que fizeram; \\ Cale-se de Alexandre e de Trajano \\ A fama das victórias que tiveram; \\ Que eu canto o peito ilustre Lusitano, \\ A quem Neptuno e Marte obedeceram. \\ Cesse tudo o que a Musa antiga canta, \\ Que outro valor mais alto se alevanta. (CAMÕES n.d., p. 44) \\ [Boast no more about the [wise] Greek \\ Or the long odyssey of Trojan Aeneas; \\ Enough of the oriental conquests \\ Of great Alexander and of Trajan; \\ I sing of the famous Portuguese \\ To whom both Mars and Neptune bowed. \\ Abandon all the ancient Muse revered, \\ A loftier code of honour has appeared] (WHITE)
}

"Sábio Grego" and "Tróiano" are Homer's Ulysses and Virgil's Aeneas and, for Camões, Ulysses is a personification of the "ilustre Lusitano" who, standing with the collective Lusitanian navigators, represents the first Portuguese "imagined community" (BHABHA, 1994; ANDERSON, 1991). Camões's epic poem celebrates the Portuguese language, in line with European notions of nationhood in the Renaissance period, whilst the Portuguese were spreading across the globe during their maritime enterprise. Yet, these notions refer not only to those Ulysses-style seafarers who left in search of adventure but also, for example, to the voiceless 
Inquisition-persecuted Portuguese Jews and non-Catholic nationals seeking survival through exile in the Old and New World.

As we read in the Encyclopaedia Judaica, in the fifteenth and sixteenth centuries, the perception for many in the New World was that Portuguese nationality was indistinguishable from Portuguese Jewish identity (Sephardic Jewish, that is, Marrano, New Christian, and Cryptic). This reality - to the extension that being Portuguese became synonymous with being Jewish - became "ubiquitous in the Old and New World centers of trade, (...) much to the consternation of the gentile Portuguese travellers" (1971, p.923). Underpinning a discourse of Portugueseness which always splits the nation within - therefore, is the need to forget what Ernest Renan describes as the "massacres and terror" that live in the memory of the nation, as part of family history (RENAN, 1990, pp. 10-11), which Pessoa does not forget. Consequently, narratives of a Portuguese national identity must include a reminder to every young woman and man in Portugal about the persecution of their family members by the Portuguese Inquisition between 1515 and 1821, and during Salazar/ Caetano's dictatorship, from the early 1930s until 1974. Pessoa was aware of, and familiar with, Portugal's historical past as the Portuguese Inquisition persecuted Sancho Pessoa, one of the poet's relatives, for the "crime" of Judaism (QUADROS, 1985, p. 21). Hence, he compares Salazar's "directrizes" to Portuguese intellectuals with the Inquisition's persecution of all non-Catholic nationals, for instance, by saying "com 'directrizes' à arte/ reata-se a tradição,/ e juntam-se Apollo e Marte/ no Theatro Nacional,/ que é onde era a Inquisição" [with "restrictions" on art/ tradition is (re)enacted/ with Apollo and Mars/ in the National Theatre/ which is where the Inquisition took place] (PESSOA qtd. In LOPES, 1993, pp. 377-78).

Pessoa's Ulysses of modernity is an identity of mute creativity of dispossessed, nameless, and displaced identities whose creativity trespasses all forbidden boundaries and knowledge of the time. In this way, he opens cultural spaces for marginal identities in modernity. In The Lusiads, however, the (Portuguese) Ulysses, represented by Vasco da Gama, is the first major European to discover the tropics and the Orient. He does so by trespassing the farthest limits that Hercules imposes on humankind when venturing into a voyage that would take him to gain knowledge of a new world. The discoveries attached to da Gama's maritime 
explorations are much more than a sixteenth-century oceanic tour from Lisbon to India. As White describes:

(...) the confirmation by the late-fifteenth century Europeans that the world was much larger than the Mediterranean basin with parts of the east attached was matched a century later by proof that the earth was not the center of the universe (...) Both discoveries posed a challenge to existing beliefs from which the world, in and beyond Europe, is still recovering (WHITE, 1997, x; emphasis added).

Both The Lusiads and The Odyssey reconstruct humankind's position in the world and the course of human affairs. Benedict Anderson's conception of a nation traces the origins of the rise of national consciousness; his "imagined communities" enable the possibility for an expansion on the dispersal of nations and culture(s) throughout the world as the nation departs from its original territory. A phenomenon that is indeed closely related to the geography of colonial conquest, for instance, Portuguese becomes a language of diasporas and of double identities. In Anderson's words:

in an anthropological spirit, then, I propose the following definition of the nation: it is an imagined political community-and imagined as both inherently limited and sovereign. It is imagined because the members of even the smallest nation will never know most of their fellow-members, meet them, or even hear about them, yet in the minds of each lives the image of their communion (ANDERSON, 1991, pp. 6-7).

The theory of Benedict Anderson's "Imagined Communities," therefore, is a concept through which one may interpret Camões's epic as the first Portuguese imagined community. While, the latter dramatizes the voyages of the (Greek) Ulysses and Aeneas as cultural events, it also narrates the Portuguese as the first nation connecting the world by sea. Moreover, it voices the diasporic journey of a nation, for soon after Camões's death, on June 1oth 1580, and following the disappearance of D. Sebastian, the Portuguese King, Portugal lost its independence as the throne passed to Philip II of Spain. As a result, the nation becomes an imagined community of dispersal in the world, and its mapping takes a form that is no longer restricted to the boundaries of the territory. Above all, Pessoa's Ulysses of modernity is the poet's (trans)creation of a displaced Ulysses, away from Camões's classical Ulysses of the past, toward modern nationhood. 
Ulysses is a leitmotif of transmutability for Fernando Pessoa's reconceptualization of nationhood. While in Camões's epic, Ulysses is an archetype of the first Portuguese "imagined community" scattered across the globe in the form of nation and narration, in Os Lusíadas, Pessoa's Ulysses of modernity is an identity of "mute" creativity of dispossessed, nameless, and displaced identities:

\author{
"Ulisses" \\ O mito é o nada que é tudo. \\ O mesmo sol que abre os céus \\ É um mito brilhante e mudo - \\ O corpo morto de Deus, \\ Vivo e desnudo. \\ Este, que aqui aportou, \\ Foi por não ser existindo. \\ Sem existir nos bastou. \\ Por não ter vindo foi vindo \\ E nos criou. \\ Assim a lenda escorre \\ A entrar na realidade. \\ E a fecundá-la decorre. \\ Em baixo, a vida, metade \\ De nada, morre. (PESSOA, p. 19) \\ [Myth is nothingness that is all. \\ The same sun that shines in the skies \\ Is a brilliant and mute myth - \\ The dead body of God, \\ Alive and uncovered. \\ He, who harboured here, \\ Was despite not-being. \\ Without existence he sufficed us. \\ Without arriving he made it \\ And created us. \\ In this way the legend flows \\ Across the threshold of reality, \\ creativity, and its processes. \\ Below, life, half \\ of nothing, dies] (my translation).
}

Pessoa's Ulysses is the myth/mythical figure that creates the Portuguese despite his nothingness - "o nada que é tudo" -, as it suggests Ulysses's and the nation's impressive range of mutations that result from a series of displacements and creativity. He is "nada" [nothing] and also "tudo" [everything]; he is "brilhante" [brilliant] and "mudo" [mute], "vivo" [alive], God's dead body "desnudo" [uncovered]; he "aportou” [harbored], 
and "foi por não ser," "existindo" nevertheless [was despite not being]; he "nos criou" [created the nation] despite "não ter vindo" [not arriving]. As we read in Mensagem, even though "os Deuses vendem quando dão/ compra-se a glória com a desgraça” [gods sell when they give/ glory comes with disgrace] (PESSOA, 2004, p.16), "Deus é o agente" [God is the agent] of "todo o começo involuntário" [all involuntary beginnings] (PESSOA, 2004, p. 21) in which all "sonhos são Deus" (PESSOA, 2004, p. 71, italics added) [dreams are God].

Being a metaphor for human dreams and an agent of mankind's "começo involuntário" [involuntary beginning], God is alive and uncovered by the nation's desire, whose dreams make of God an agent of negotiation rather than negation, for otherwise God's "corpo morto" [dead body] would not be "vivo" [alive]. In "Ulisses" God is neither dead nor transcendental but humankind's mediation, as God is alive in people's desire for creating and knowing (by uncovering the unknown). As we read in Mensagem, "Deus quis que a terra fosse toda uma/ que o mar unisse, já não separasse" [God wanted the earth to be one/ the sea to connect, and to separate no longer] (PESSOA, 2004. p. 49). Most importantly, Pessoa desires a dialogue that embraces the mute and the nameless. For instance, when Pêro de Vaz Caminha writes to the Portuguese, King D. Manuel I, in 1500, telling him about the lands and people of Brazil through the eyes of the Portuguese, he does not mention that there is another side to the discoveries:

\begin{abstract}
the sailors, the women - homeless, without possession and without an economy - and the native - together make a triangle of the dispossessed. The natives, living outside European feudalism and mercantilism, are only granted a name, an individuality in the future, through Christian baptism. In partial contrast the land, brought into existence for the western world by the acts of possession and naming, remains, for many a year, no less forsaken (SANTIAGO, 2000, p.330).
\end{abstract}

Pessoa's revival of Ulysses in Mensagem, therefore, reaffirms the transmutability of the nation both as cultural encounter in the development of the nation, and as a permanent dialogue between tradition and modernity as it is a translational process inherent to the nation's mutability. The poem communicates the creative energy of the Portuguese and the potential of the nation to overcome the country's various socio-political hardships in Pessoa's time, inside and outside the territorial frontiers. The potential of the nation, in Pessoa, however, is 
only attainable if one "feels" the signs and symbols as living "gente" and allows one's creative energy to interact with the sensible world. With this in mind, "Ulisses" "escorre" [flows] into reality; he is "fertile" and, as a consequence, he is able to enter reality. Furthermore, he is part of life but greater than life "embaixo' [below], in which "metade/ de nada, morre" [half/ of nothing, dies].

Ulysses, the etymological founder of Lisbon, and legend of the diasporic nation in Os Lusíadas, is in Mensagem a figure in constant transmutation and transcreation of the modern nation. He is the mute hero who resurfaces as life above and "embaixo" [below], always wanting to "entrar na realidade" [enter reality] - a reality in which all is one. He is a figure transversal to the world's literary heritage of verses and reverses that are, in this case, the heroic Ulysses and the mute Ulysses in Portuguese. Pessoa's modern Ulysses is "o mesmo sol que abre os céus" [the same sun that shines in the skies] and turns all humans into family members as they contemplate the same sun or God; these are, therefore, the poet's metaphors expressing the same idea in different languages. Moreover, Pessoa's Ulysses is an archetype of the dispossessed and of marginal identities whonever gets to be recognized for contributing to the nation.

In Mensagem, Ulysses is a hyphenated poet-hero who exchanges Camões's Ulysses's sword for the pen, and the religious wars for the poetic(s) word. Pessoa wants the reader to interpret his protean "Ulisses" as an antidote to the stagnation of the nation and, in this way, creates civilization by driving it towards modernity. He is mute, yet he is one who "por não ter vindo foi vindo/e nos criou" [was despite not-being/ andcreated us]. Thus, Pessoa's Ulysses of modernity transits inwardly and within the nation, embodying the ambivalence in the performative discourses of modernity. For Pessoa, moreover, the nation is a group of people living in the same place or in different places, like Joyce's Leopold Bloom, not only Irish and Jewish, but also Catholic and Protestant. By not dispersing outwards and experiencing the Diaspora for several years, as in Homer's and Camões's narratives on the nation; or towards hell, as in Dante's Divine Comedy, Pessoa's Mensagem modernizes these classic narratives. It is by writing a juxtaposition of the nations in time and space, suggesting a recurrence in time in the form of displacements (RICOEUR,1980, p. 186), that the poet modernizes the classic narratives. This juxtapositioning of the Greek, Italian, and Portuguese classical narratives is, in Pessoa, a perception of time as a "circular" (RICOEUR, 
1980, p. 186) "futuro do passado" [future of the past] where negotiation of culture in tradition and modernity become an alchemic transformation for cultural purposes.

Pessoa's modern "Ulisses" fights a warless war, and, in the course of metempsychosis, he assumes so many forms that he becomes them all during this course of nation. As a result of transmutation and metempsychosis, a "nobody" can be hero-like - as is Homer's Odysseus, who dresses as a poor old man when he returns to Ithaca, regaining his place by merit alone. He does so without needing to slash his rivals, like Joyce's Leopold Bloom, who decides that his troubles are almost nothing in comparison to all the daily horrors that occur under the same stars that shine for everyone in the sky. Pessoa's Ulysses, above all, liberates the powerless, suggesting other legitimate readings for their suffering, by depicting the potential of their individual and collective merit.

Suggesting that "o mesmo sol que abre os céus" [the same sun that shines in the skies] shines to everybody as the dead body of God uncovered, Pessoa's Ulysses is a transnational figure of modernity in the search of negotiation instead of negation. His language in the poem, intends to disrupt the binaries that split the nation from within. As Pessoa notes, "racial mixture is the basis for the foundation of all nations, as culture contacts of their development" (emphasis added) (PESSOA qtd. in LOPES, 1993, p. 293). In this way, Pessoa argues that nations are in permanent change as there are transversal transits of people and cultures within the nations, whilst contributing to their development. As Bhabha (1994, p. 247) also notes: "the transnational dimension of cultural transformation - migration, diaspora, displacement, relocation - makes the process of cultural translation a complex form of significance". In the poem "Ulysses," Pessoa portrays displacement as a source of creativity which, ultimately, generates the creation of nationhood as the nation is, after all, a series of displacements. For these reasons, Pessoa argues for the potential of difference and displacements in the development of nations, and he voices those nationals who became mute. By suggesting the potencial of creativity and transmutation, Pessoa's Ulysses is the modern founder of the Portuguese, who "por não ter vindo foi vindo/ E nos criou" [without arriving he arrived/ and created us], giving all Portuguese the resources to overcome Cyclops and all the "Monstrengos" of modernity and, particularly, our individual "monstrengos" [monsters]. One of those individual and social monsters would be failing to see the cultural 
transformation of displacements as a complex form of significance that is the antidote for the decadence of the nation.

Pessoa's (trans)mutable "Ulisses" is also a Ulysses of otherness within, travelling nowhere, rather than of traditional sameness, alwayson-the-search-for-otherness or "além." With this concept in mind, Pessoa disrupts the historicism of the nation by suggesting a time and space for the nation as "estados mentais e não geográficos" [mental states rather than geographical]. By interpreting history in a novel way, Pessoa uncovers the construct of civilization of his society and suggests a mental state for the Portuguese that disrupts the stillness of such construct. For Boitani, however, Pessoa's oxymoronic Ulysses, “o mito é o nada que é tudo" [myth is nothingness that is all], is an ironic device. As he says - in the reappearance of Ulysses - twentieth-century literature is "continually returning to ancient myth for explanations of the foundations of history and poetry, using it almost as a touchstone between the "everything and the nothing" (BOITANI, 1994, pp. 124-25). Boitani argues that the "everything and nothing" leads to three twentieth-century conclusions: word, enigma, and silence, where "the myth [is] an arkhe of reality within the fiction: a beginning in myth and poetry which foreshadows a slender hope of the imminent rebirth of life and culture" (1994, p. 126; emphasis added). Indeed, Portuguese society in Pessoa's time was in need of are birth of life and culture; it was a society where the poet yearned to improve with new ideas and emotions of modernity and civilization. As Pessoa says in relation to "o caso mental português" [the Portuguese mental case] on November 3oth 1932:

se fosse preciso usar de uma só palavra para com ela definir o estado presente da mentalidade portuguesa, a palavra seria "provincianismo." (...) Os homens, desde que entre eles se levantou a ilusão ou realidade chamada civilização, passaram a viver, em relação a ela, de uma de três maneiras, que definirei por símbolos, dizendo que vivem ou como campónios, ou como provincianos, ou como citadinos. Não se esqueça que trato de estados mentais e não geográficos, e que portanto o campónio ou o provinciano pode ter vivido sempre em cidade, e o citadino sempre no que lhe é natural desterro (PESSOA, n.d., 167, p.169).

[if it were necessary to use a single word to define the present state of the Portuguese mentality, that word would be "provincianism." (...) Men, from the time the illusion or reality of civilization arose among them, have lived, in relation to it, in one of three ways, which I will define by symbols, saying that they live as rustics, as provincials or as urbanites. Do not forget that I am dealing with mental states and not geographical ones, and that, 
therefore, the rustics and the provincials may have always lived in the city, and the urbanites may have always lived where exile is natural to them] (my translation).

When arguing that these three symbols of "provincianismo" are "estados mentais e não geográficos," Pessoa is confirming that culture in Portuguese (Portuguese being semi-heteronym Bernardo Soares's patria) is a space of interaction for the world's cultural heritage, in particular, for modern poetry. Culture, the poet argues, is not an "ilusão ou realidade chamada civilização" [an illusion or reality known as civilization] but a non-located place, where the senses and the imagination are synonymous with modernity.

This view of culture is in contrast to tradition without patriotism where culture perpetuates itself in terms of an essentialist position whilst projecting a temporality of the past to the future. Thus, if modernity moves away from a "provincianismo mental e não geográfico" [mental, not geographical provincianism] then Pessoa's Ulysses of modernity is a creator of culture and civilization. Culture and civilization, therefore, are only possible through the senses and imagination of diasporic and settled identities, and in the cultural contacts experienced by the development of the nation.

The diasporic concept as a creator of culture for Pessoa, a (re)creator of myths in Portuguese culture, relates to the myth of the fifth empire after Greece, Rome, Christianity, and Europe - the empires of times past. Such awareness occurs when Pessoa asserts in Mensagem that humankind has "por vida a sepultura" [life as a death sentence] ("O Quinto Império" 72) if it cannot dream "sonhos que são Deus” [dreams that are God], and Pessoa further asks us, if the fifth empire is:

(...) um imperialismo de gramáticos? O imperialismo dos gramáticos dura mais e vai mais fundo que o dos generais. (...) um imperialismo de poetas? Seja, a frase não é ridícula senão para quem defende o antigo imperialismo ridículo. $\mathrm{O}$ imperialismo de poetas dura e domina; o dos políticos passa e esquece, se o não lembrar o poeta que os cante (PESSOA qtd. in SERRÃO 1979a, p. 240).

[(...) an imperialism of grammarians? An imperialism of grammarians lasts longer and goes more in dept than those of the generals. (...) An imperialism of poets? Be it, the statement is ridiculous only to those who defend the ridiculous imperialism of the past. Imperialisms of poets endure and dominate; those of politicians are short lived and forgotten, if not remembered by poets in their work]. (my translation) 
Pessoa invites the reader to understand the future of the Portuguese past - the fifth empire of culture in Portuguese -, but in order to do so, one has to learn how to reread and reinterpret the signs and symbols of the nation.

\section{ALBERTO CAEIRO, THE SETTLED ARGONAUT OF SENSATIONS: THE MIGRANT MASTER FOR HUMANITY}

It is within a vision perceived through the eyes of the imagination and interwoven with sensations that we are allowed a negotiation capable of destroying the negative polarities between knowledge and its objects, such as the case with modern society's monsters, "rotina, estupidez, incultura" [routine, sensationlessness, inculture] (PESSOA qtd. in LOPES 1993, p. 31). This capacity to see through the eyes of the imagination is in Pessoa's poem,“Ulisses," not only the (s)word with which to fight a warless war but also a process of poetics for, as "mestre" [master] Caeiro says: "o essencial é saber ver,/ saber ver sem estar a pensar,/ saber ver quando se vê,/ nem ver quando se pensa" [the essential is to know how to see/ to know how to see without thinking/ knowing how to see when you are seeing/ not seeing when you are thinking] (CAEIRO, 2009, p.58).

Migrant Alberto Caeiro is the settled migrant who travels in his sensations. His flocks of sheep are his thoughts while poetry is his sensations. In O Guardador de Rebanhos he, the migrant Caeiro, offers his verses to humanity. In his words:

\footnotetext{
Da mais alta janela da minha casa

Com um lenço branco digo adeus

Aos meus versos que partem para a humanidade.

E não estou alegre nem triste.

Esse é o destino dos meus versos.

Escrevi-os e devo mostrá-los a todos

Porque não posso fazer o contrário

Como a flor não pode esconder a cor,

Nem o rio esconder que corre,

Nem a árvore esconder que dá fruto.

Ei-los que vão já longe como que na diligência

E eu sem querer sinto pena

Como uma dor no corpo.

Quem sabe quem os lerá?

Quem sabe a que mãos irão?

Flor, colheu-me o meu destino para os olhos.
} 
Árvore, arrancaram-me os frutos para as bocas.

Rio, o destino da minha água era não ficar em mim.

Submeto-me e sinto-me quase alegre,

Quase alegre como quem se cansa de estar triste.

Ide, ide de mim!

Passa a árvore e fica dispersa pela Natureza.

Murcha a flor e o seu pó dura sempre.

Corre o rio e entra no mar e a sua água é sempre a que foi sua.

Passo e fico, como o Universo. (CAEIRO, 2009, p.86)

[From the highest window of my house

With a white scarf I say goodbye

To my verses that depart to humanity.

And I am not happy or sad.

That is the destiny of my verses.

I have written them, and I should show them to everyone

Because I cannot do the opposite

Like the flower cannot hide its colour,

Nor the river hide that it flows,

Nor the tree hide that it is fruitful.

There they are far away in a transit

And unintentionally I feel pity

Like pain in my body.

Who knows who will read them?

Who knows the hands that will hold them?

Flower, picked was my destiny for the eyes.

Tree, ripped were my fruits for the mouths.

River, the destiny of my water was not to stay in me.

I submit myself and feel almost happy,

Almost happy as someone who gets tired of being sad.

Depart, and go from me!

The tree drops and disperses through Nature.

The flower fades and its dust will be forever.

The river runs and rushes into the sea and yet its water is always the same water that was its.

I pass by yet I stay, like the Universe]. (my translation)

When Caeiro disperses his verses throughout the universe and for humanity, and tells us that it is the destiny of his verses, it is also important to note that Pessoa tells us that master Caeiro "escrevia mal o português" [wrote Portuguese badly] (PESSOA qtd. in ZENITH, MARTINS, 2008, p. 165). In contrast, the language of heteronym Ricardo Reis, self-exiled in Brazil, is of a "purismo exagerado" [of an exaggerated purism] (PESSOA qtd. in QADROS, 1968, p. 199). Caeiro's scattering of his verses for humanity is Pessoa's "Quinto Império" in Mensagem, emphasizing the "visão que a alma tem" [vision of the spirit] (2009, p. 72). 
This vision of the spirit is above all philosophies and metaphysics for, as Caeiro says, "os poetas místicos são filósofos doentes,/ e os filósofos são homens doidos" [mystical poets are unsound philosophers,/ and philosophers are mad men] (2009, p.62). The cure for their illnesses, Caeiro argues, is to unlearn what they have learned. For this, they ought to undress the artificiality of their knowledge in order to become "o Argonauta das sensações verdadeiras" [an argonaut of true sensations], like Caeiro, whose poetic voice proffers that:

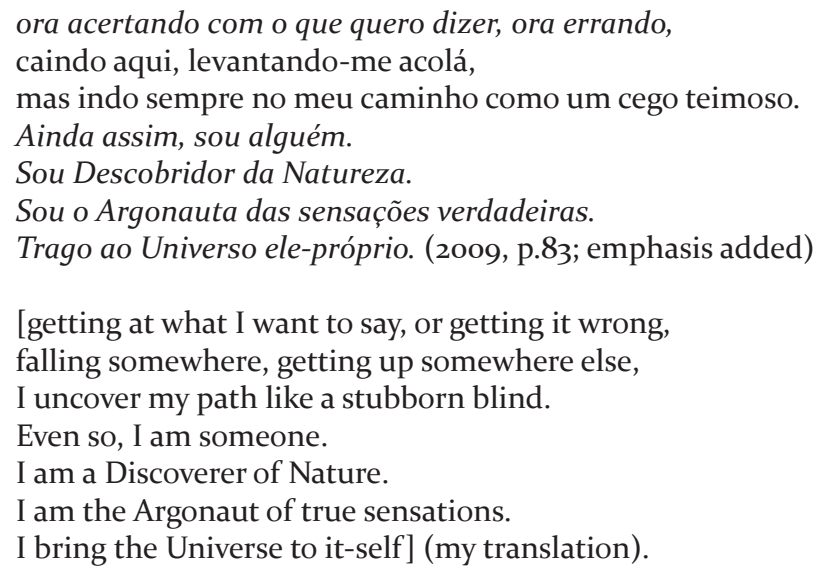

By being displaced and, therefore, a subject-object "Argonauta das sensações verdadeiras," Caeiro embodies Pessoa's artistic movement Sensationism. Sensationism, Pessoa's creationalism, is "uma espécie de poética entendida e entendível como a coerência da incoerência, que em si mesma conseguisse abarcar todas as tendências do início do século XX" [as a poetics understood and perceptible as coherence of the incoherent, a paradigm in which "toda a verdade é, afinal, em si mesma, contraditória" [all truth is, in itself, contradictory] (MARTINS, 2008, p. 790).

Caeiro is an Argonaut of true sensations who, in displacement, is able to construct coherence out of what he perceives as incoherent in order to develop a sense of belonging and contribute to what is now his new "home." Sensationism is, foremost, a strategy with the purpose of negotiating mental spaces. Departing from what is familiar to him Lisbon - Caeiro learns how to create familiarity in his new unfamiliar rural setting by revealing that there are no monological truths, that is, coherent "truths." Consequently, he shows that coherence is an external "truth" of monological constructs that impose themselves on 
individuals, not only alienating them but also by becoming obstacles to their inner integration. Caeiro challenges readers to liberate themselves from "external coherences" so that one may have the freedom to identify with the coherent "truths" of the world and contribute positively to humanity. For this liberation that enables the construct of familiar spaces and a location to be called "home," Caeiro - the master of all heteronyms, including Pessoa - suggests a vision of Jesus as the "eternal child." If Jesus, a Jew, is a God amongst other Gods, this can only be because he sees through the eyes of the imagination and senses poetry in everything. As Caeiro utters, Jesus is "a Eterna criança, o deus que faltava" [the Eternal child, the god that was needed], a "criança tão humana que é divina/ é esta minha quotidiana vida de poeta/ e é porque anda sempre comigo que eu sou poeta sempre" [a child who, for being so human, is divine/ and this is the everyday life of a poet/ and it is because he is always with me that I am always a poet] (2009, p.38).

Caeiro's "Eterna criança” [eternal child] is a metaphor for the eyes of imagination, a paradigm of Caeiro's poetry as "coerência da incoerência" [coherence of the incoherent] which brings "ao Universo ele-próprio" [to the Universe it-self]. It is by destroying that the negative polarities between knowledge and its objects become a subject-object of his poetry and perceptions and that Caeiro's eternal child is a source of revelations. Thus, while Caeiro is a settled "alguém," a migrant "Argonauta das sensações verdadeiras" in Mensagem, Ulysses is a diasporic poet-hero going nowhere, also an "Argonauta das sensações verdadeiras." Forever trespassing the prohibited signs and symbols in transcreations, Ulysses also reveals the (uni)verse in Portuguese to the world literature, that is, "ao Universo ele-próprio" [the universe to it-self]. Migrant Caeiro is the heteronym who has not gone beyond primary school; the one whose language - as Pessoa says - is poor; the one who, inversely, transits from the capital to the country; yet, he is the master of all the heteronyms including Pessoa, and the one who disperses his verses to the humanity - in the space of interactions - of settled and diasporic identities. Pessoa transcreates a Ulysses of modernity in Mensagem to create culture in Portuguese, as his Ulysses of modernity is a diasporic identity travelling nowhere, other than in trespassing signs and symbols in Portuguese.

Heteronym Álvaro de Campos, for instance, is yet another diasporic identity who has lived and studied in Scotland, travelled in England and to the Orient, and is now unemployed in Lisbon. Heteronym Ricardo 
Reis exiles himself to Brazil. These are some of the examples in his work where one finds reflections of his diasporic nationhood and on several types of displacement. As Darlene Sadlier suggests, Pessoa's heteronyms "enabled him to manipulate single stylistic tendencies within single poems, where he was able to reconcile powerful oppositions" (1997, p.109; emphasis added).

\section{CONCLUSION}

By creating new mappings for the nation, Pessoa not only trespasses the frontiers of nation-States with his heteronyms and his mute Ulysses of modernity, but he also disrupts the hierarchical system of the past by creating a master, Caeiro. The latter, instead of displaying the traits of a master, has the characteristics of those who were marginalized by the Portuguese society of the time. Likewise, in Pessoa's poem "Ulisses," life below is a simile of life above, as life in permanent negotiation. Whilst, Portuguese society in Pessoa's time suffers from a "psiquismo nacional" of stagnation and decay, represented as life below, as "metade de nada" [half of nothing], the poet suggests the reinvigorating circularity of a modern Ulysses, a "criador de civilização" [creator of civilization]. Therefore, voyaging and poetry in Pessoa's poem "Ulisses" negotiates the culture and civilization of the world's literary heritage in Portuguese, in his time and in times to come. In other words, for Pessoa, poetry is the process through which the poet examines what is true for him. One of the poet's "verdades fundamentais ou cabalístiscas" [Kabbalistic or foundational truths], is that "o que está por cima é como o que está por baixo [and] quando o discípulo está pronto [for initiation], o Mestre está pronto também” [what is above is like what is below and when the disciple is ready the master is also ready] (PESSOA qtd. in CENTENO, 1985b, p.53), as the relationship between poetry and alchemy is a subject to which the poet was highly dedicated throughout his life (PESSOA qtd. in CENTENO, 1985a, p. 73).

As displaced identities, Pessoa's "mute" Ulysses and migrant Alberto Caeiro "double writing" of culture in Portuguese trespasses the forbidden signs and symbols of the nation as a cultural force. Suggesting a recurrence in time in the form of displacements (RICOEUR, 1980, p.186), Pessoa's juxtapositioning of the Greek, Italian and Portuguese classical narratives portrays a "circular time" (RICOEUR, 1980, p.186): a literary 
"futuro do passado" [future of the past]. Displacement, therefore, enables a negotiation of culture in tradition and modernity as an alchemic transformation for cultural purpose.

The novelty of Pessoa's reconceptualization of nationhood is that the poet's heteronyms are the paramount example of his non-positioning of Portugal's national and literary identity. Pessoa's mapping of the nation repositions diasporic and settled identities, whilst displacing the historicism that has dominated discussions of the nation throughout the centuries. Pessoa creates a nationhood with a transnational dimension of cultural transformation - migration, diaspora, displacement, relocation that makes the process of cultural translation a complex form of significance (BHABHA, 1994, p.24) so that we, diasporic and settled identities today, may learn a transmutation for humanity and, to paraphrase the migrant master, "bring the universe to itself in a (post)modern world."

\section{BIBLIOGRAPHY}

ANDERSON, Benedict. Imagined Communities. London: Verso, 1991.

BHABHA, Homi. The Location of Culture. London: Routledge, 1994.

BOITANI, Piero. The Shadows of Ulysses: Figures of a Myth. Oxford: Oxford UP, 1994.

CAEIRO, Alberto. Poesia de Alberto Caeiro. Eds. Fernando Cabral Martins and Richard Zenith. 3rd ed. Lisbon: Assírio \& Alvim, 2009.

CAMÕES, Luís de Vaz. Os Lusíadas. 2nd ed. Lisbon: Biblioteca Ulisseia, n.d.

CENTENO, Yvette. Fernando Pessoa: o Amor, a Morte, a Iniciação. Lisbon: A Regra do Jogo, 1985a.

CENTENO, Yvette. Fernando Pessoa e a Filosofia Hermética. Lisbon: Editorial Presença, 1985b.

Encyclopaedia Judaica. Vol. 13. Jerusalem: Keter Publishing House, 1971.

JOYCE, James. Ulysses. Oxford, UK: Oxford UP, 1922.

"Lisbon". Encyclopæedia Britannica. Encyclopæedia Britannica Online. Encyclopædia Britannica Inc., 2012. Web. 25 Sep. 2012.

LOPES, Teresa Rita. Ed. Pessoa Inédito. Lisbon: Livros Horizonte, 1993. 


$$
540 \text { - Remate de Males } 36.2
$$

MARTINS, Fernando Cabral. Ed. Dicionário de Fernando Pessoa e do Modernismo Português. Lisbon: Editorial Caminho, 2008.

MATTOSO, José. A identidade Nacional. Lisbon: Gradiva, 2008.

PESSOA, Fernando. Textos de Crítica e de Intervenção de Fernando Pessoa. Lisbon: Ática, n.d.

PESSOA, Fernando. Mensagem. Ed. Fernando Cabral Martins. Lisbon: Assírio and Alvim, 2004 .

QUADROS, António. Escritos Íntimos, Cartas e Páginas Autobiográficas, Fernando Pessoa. Lisbon: Publicações Europa-América, 1986.

QUADROS, António. Poesias de Álvaro de Campos. 2nd Ed. Sintra: Publicações EuropaAmérica, 1985 .

RENAN, Ernest. “What Is a Nation?”. Nation and Narration. Ed. Homi K. Bhabha. London: Routledge, 1990, pp. 8-22.

RICOEUR, Paul. “Narrative Time”. Critical Enquiry 7. 1 On Narrative (Autumn, 1980): pp 169-90.

SADLIER, Darlene. "Nationalism, Modernity, and the Formation of Fernando Pessoa's Aesthetic”. Luso-Brazilian Review 34.2 (Winter 1997), pp. 109-22.

SANTIAGO, Silviano. "Destinations of a letter, predestinations of a country". Interventions 2.3 (2000), pp. 330-42.

SERRÃO, Joel. Fernando Pessoa sobre Portugal. Lisbon: Ática, 1979a.

WHITE, L. Luis Vaz de Camões: The Lusiads. Oxford: Oxford University Press, 1997. 